\title{
COMMERCIALLY IMPORTANT PROPERTIES OF PLANTS OF THE GENUS Plantago
}

\author{
${ }^{1}$ Elżbieta Weryszko-Chmielewska, ${ }^{2}$ Anna Matysik-Woźniak, \\ ${ }^{1}$ Aneta Sulborska, ${ }^{2}$ Robert Rejdak
}

\author{
${ }^{1}$ Department of Botany, University of Life Sciences in Lublin, Akademicka 15, 20-950 Lublin, Poland \\ ${ }^{2}$ Department of General Ophtalmology, Medical University of Lublin, Chmielna 1, 20-079 Lublin, Poland \\ e-mail: elzbieta.weryszko@up.lublin.pl
}

Received: 10.10.2011

\begin{abstract}
The centuries-old experience of folk medicine, nutritional traditions, and the results of numerous research studies show that plants of the genus Plantago can be used for medicinal, cosmetic, dietetic, and ritual purposes.

In the phytochemical composition of Plantago, there is an abundance of biologically active substances (among others, glycosides, flavonoids, polysaccharides, and vitamins) exhibiting beneficial effects and, simultaneously, there is a low content of compounds that may exert a toxic effect. Scientific research has confirmed that Plantago plants have antioxidative, apoptosis-inhibiting, protective, healing-enhancing, spasmolytic, anthelmintic, and antimicrobial properties; they inhibit the development of some tumours, reduce the level of lipids in blood and inhibit tissue glycation. In phytotherapy, leaves, stems, and/or seeds of different plantain species are used.

Plantago leaves and seeds are also used to manufacture creams, lotions, and face masks. Different parts of these plants (fresh plant material, extracts, or isolated substances) are also used in human and animal nutrition. Plantain leaves can be eaten like lettuce or added to salads, fried in pastry, used to prepare a tea, juice, or wine. Its seeds are added to cakes, bread, breakfast cereals, ice cream, and drinks, or they are cooked like groats. Animals fed with plantain can live longer and are healthier, while meat derived from such animals is tastier and healthier to humans. Plantago seeds are readily eaten by cage birds.

Plantain pollen, produced in large amounts (up to 20,000 pollen grains per 1 stamen of $P$. lancolata), can cause allergies in sensitive people. Due to a long flowering period of plants of the genus Plantago, the effect of the allergenic factor persists for many weeks. In Poland days with the maximum concentration of airborne plantain pollen most often occur in July.
\end{abstract}

Key words: Plantago, medicinal uses, cosmetics, edible plants, animal feed, allergenic pollen.

\section{THE HISTORY OF USE OF Plantago PLANTS}

Various Plantago species have been used as food for humans and animals as well as medicinal, cosmetic, and ritual plants. The traditional and multiple uses of these plants are confirmed by ethnobotanical and ethnopharmacological research ( $\mathrm{S}$ a muelse n, 2000; Ł u c z a j, 2004; C or nara et al. 2009).

The medicinal properties of Plantago lanceolata have been known since ancient times. This species was used in China already 3000 years ago. In ancient Rome Pliny the Elder recommended plantain as a medicine for 24 diseases. In folk medicine of many countries, the aerial parts of $P$. lanceolata are used externally and internally to treat different ailments ( $\mathrm{N}$ ow i ń $\mathrm{ski}, 1983$; Nishibe, 2002). In Italy the resin of $P$. lanceolata was used as a substitute for incense smoke in church rituals. Inflorescences of this plantain, mixed with stems of other plants (Helichrysum, Thymus), were burnt to perfume clothes and rooms with the smell of smoke (C or n a r a et al. 2009).

Plantago major was included among the most important herbs in the Chinese herbarium dated from the 1st century A.D. It was also used in ancient Greece and Rome. Dioscorides, Pliny the Elder, and Galen recommended it against snake and scorpion bites. It was also used in therapy during the Middle Ages ( $\mathrm{No}$ wińs ki, 1983; S a muels e n, 2000; S trzelec$\mathrm{k} \mathrm{a}$ and Kow als ki, 2000). Seeds of $P$. major were placed in the tombs of pharaohs, while its leaves were used as a vegetable by the Chinese. Plantain was called White Man's Foot by North American Indians, since it grew everywhere where the white man appeared. The Shoshone Indians applied heated leaves of this species to wounds (C la r k, 1977). 


\section{THE CHARACTERISTICS OF THE GENUS Plantago}

The family Plantaginaceae comprises about 265 species widespread in temperate climate areas. The genus Plantago includes about 260 species of perennials, annuals and, exceptionally, shrubs (S z w e y k ow s c y, 2003). In Poland 17 species of the genus Plantago are found growing in the wild, among others, $P$. lanceolata L., P. major L., P. media L., P. arenaria Waldst. and Kit., P. maritima L., P. altissima L., $P$. patagonica Jacq., $P$. intermedia Gilib., $P$. coronopus L., P. atrata Hoppe, $P$. serpentina All., and $P$. winteri Wintg. (M i r e k et al. 2002). The first four above-mentioned taxa belong to medicinal plants. Moreover, other plantain species are included among plants used in therapy, inter alia, the ones growing in the Mediterranean area: . afra L. (= P. psyllium), P. ovata Forsk., $P$. asiatica L., and $P$. depressa Willd. (A n $\mathrm{drze}-$ je w s k a - G o le c, 1994). These plants can reproduce from seed or vegetatively from buds formed on their roots (M a urizio and Graf 1, 1969).
The leaves of plants of the genus Plantago form a ground rosette. The leaf blades are entire or denticulate. The flowers are small, bisexual, most frequently borne in spike-like inflorescences (Fig. 1A). They produce a delicate scent in some species. The perianth consists of a 3-sepalled calyx and a 4-petalled corolla forming a tube and 4 membranous lobes ( $\mathrm{Re}$ a rd o $\mathrm{n}$ et al. 2009). The androecium comprises 4 stamens fused to the corolla tube which are several times longer than the petals (Fig. 1A). In these flowers, the stamens perform the role of the attractant. In P. media, they are lily coloured and attract numerous insects ( $\mathrm{L}$ i p i n $\mathrm{s} \mathrm{k} \mathrm{i} \mathrm{,2010).} \mathrm{The} \mathrm{stamens} \mathrm{have} \mathrm{a} \mathrm{rare} \mathrm{feature} \mathrm{of} \mathrm{closing}$ their anthers at high air humidity, which protects pollen against water (Maurizio and Graf1, 1969). Plantago flowers represent an intermediate degree between anemophily and entomophily; for instance, under favourable weather conditions bees perform the pollination while collecting the pollen of P. lanceola$t a$, whereas in adverse weather its flowers are pollinated by the wind. These flowers do not produce nectar (K u g l e r, 1970).
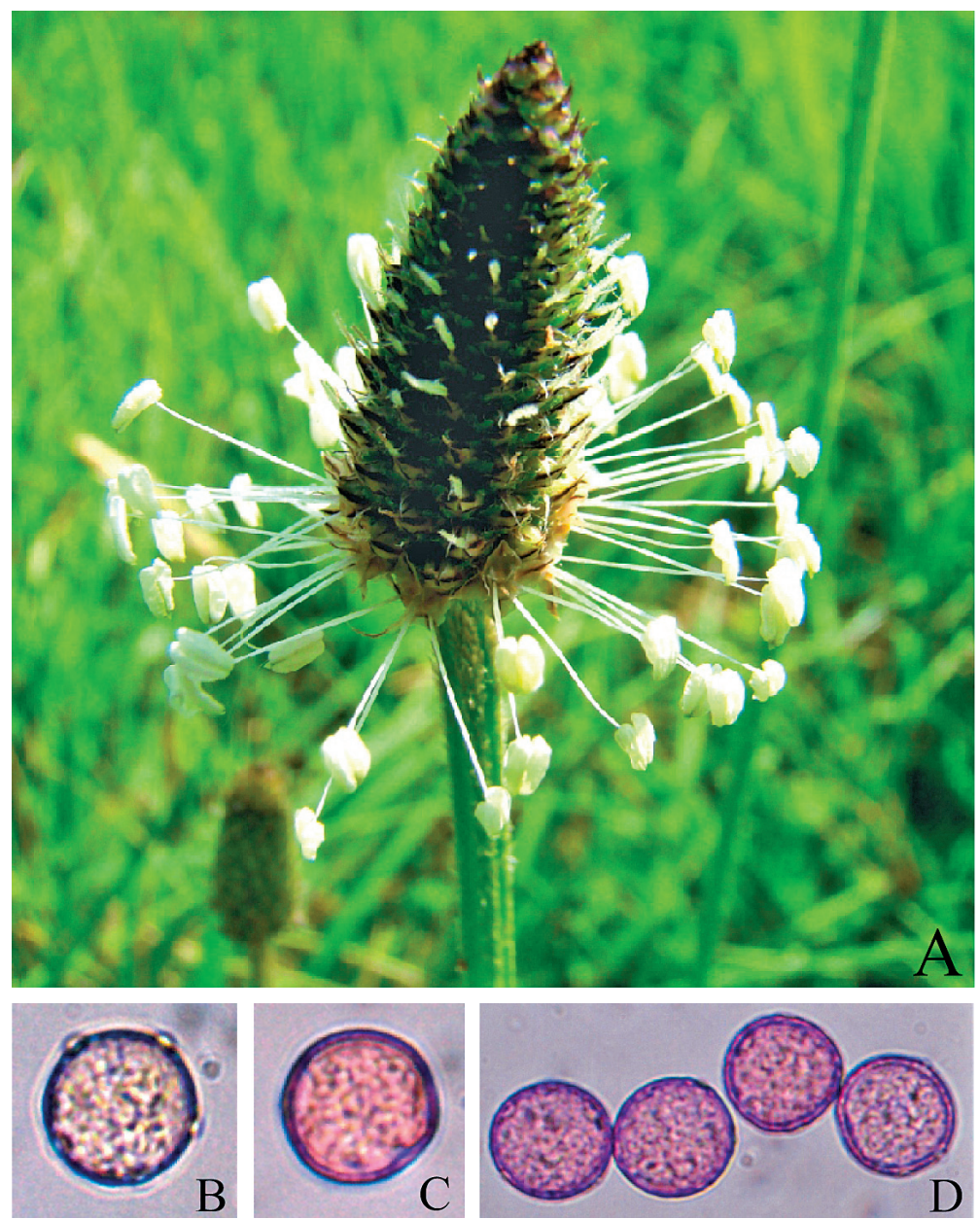

Fig. 1. Inflorescence of Plantago lanceolata (×3). B-D. Pollen grains of P. media (B) $(\times 670)$, P. major (C) ( $\times 700)$, P. lanceolata (D) (×530). 
A capsule (fruit), which opens by a lid, develops from the pistil of the superior, mostly bilocular ovary (Podhajská and Rivola, 1992; Szweykows c y , 2003). The existing research shows that fruits originating from different populations of Plantago lanceolata significantly differ in size and shape ( $\mathrm{T} \mathrm{r} \mathrm{u} \mathrm{c} \mathrm{h} \mathrm{a} \mathrm{n,}$ 2005). The fruit of Plantago has a special feature, since it dehisces and releases seeds when it is wet (hygrochasy) and closes when dry (W e b e r 1 in g, 1992). In the fruit, there are usually 2 seeds and their coat can have different shades of brown. The seeds are elliptically-shaped and their surface is smooth and shiny. In the seed coat, there are cells accumulating mucilage and, as a result of that, soaked seeds swell up quickly and stick to the medium (Maurizio and Graf1, 1969; Podhaj ská and Rivola, 1992; Ś wi dzińska, 1998).

Tab. 1.

Characteristics of some species of Plantago and their traditional medicinal uses

\begin{tabular}{|c|c|c|c|c|c|}
\hline No. & Species & Occurrence & Morphological features & Traditional medicinal use & References \\
\hline 1. & $\begin{array}{l}\text { Plantago } \\
\text { lanceolata } \mathrm{L} .\end{array}$ & $\begin{array}{l}\text { Europe, north } \\
\text { Asia, Middle } \\
\text { Asia. }\end{array}$ & $\begin{array}{l}\text { Plant height } 10-60 \mathrm{~cm} . \\
\text { Lanceolate leaves form } \\
\text { a ground rosette; brown } \\
\text { flowers borne in spikes } 1-3 \\
\text { cm long. }\end{array}$ & $\begin{array}{l}\text { Herbal infusion - } \\
\text { compresses for wounds, } \\
\text { burns; leaf juice used for } \\
\text { ulcers and eye diseases. }\end{array}$ & $\begin{array}{l}\text { Strzelecka and } \\
\text { Kowalski, 2000; } \\
\text { Podbielkowski and } \\
\text { Sudnik-Wójcikowska, } \\
2003 .\end{array}$ \\
\hline & $\begin{array}{l}\text { Plantago } \\
\text { major L. }\end{array}$ & Europe, Asia. & $\begin{array}{l}\text { Plant height up to } 40 \mathrm{~cm} \text {. } \\
\text { Ovate, entire leaves form } \\
\text { a ground rosette. Small } \\
\text { greenish flowers borne in a } \\
\text { long, cylindrical spike. }\end{array}$ & $\begin{array}{l}\text { Compresses from fresh } \\
\text { leaves for wounds and } \\
\text { ulcers; irrigation of } \\
\text { wounds with leaf infusion; } \\
\text { an antitussive agent. }\end{array}$ & $\begin{array}{l}\text { Strzelecka and } \\
\text { Kowalski, 2000; } \\
\text { Podbielkowski and } \\
\text { Sudnik-Wójcikowska, } \\
2003 \text {. }\end{array}$ \\
\hline & $\begin{array}{l}\text { Plantago } \\
\text { media L. }\end{array}$ & Europe. & $\begin{array}{l}\text { Plant height } 10-50 \mathrm{~cm} \text {. } \\
\text { Elliptical leaves borne in a } \\
\text { rosette. Fragrant flowers with } \\
\text { a whitish corolla form short } \\
\text { spikes. }\end{array}$ & $\begin{array}{l}\text { Anti-inflammatory, } \\
\text { astringent, expectorant } \\
\text { activity. }\end{array}$ & $\begin{array}{l}\text { Anioł-Kwiatkowska } \\
\text { et al., 1993; } \\
\text { Podbielkowski and } \\
\text { Sudnik-Wójcikowska, } \\
2003 .\end{array}$ \\
\hline & $\begin{array}{l}\text { Plantago arenaria } \\
\text { Waldst. and Kit. } \\
(=P . \text { indica })\end{array}$ & $\begin{array}{l}\text { Europe, west } \\
\text { Asia, west } \\
\text { Africa. }\end{array}$ & $\begin{array}{l}\text { Plant height up to } 40 \mathrm{~cm} \text {. Its } \\
\text { linear leaves are arranged } \\
\text { oppositely. Whitish flowers } \\
\text { form globular spikes growing } \\
\text { from the axils of the highest } \\
\text { leaves. }\end{array}$ & Mild purgative. & $\begin{array}{l}\text { Strzelecka and } \\
\text { Kowalski, 2000; } \\
\text { Podbielkowski and } \\
\text { Sudnik-Wójcikowska, } \\
2003 .\end{array}$ \\
\hline 5. & $\begin{array}{l}\text { Plantago } \\
\text { psyllium } \mathrm{L} . \\
(=P . \text { afra })\end{array}$ & $\begin{array}{l}\text { South } \\
\text { Europe. }\end{array}$ & $\begin{array}{l}\text { Plant height ca. } 30 \mathrm{~cm} . \\
\text { Linear, opposite leaves, } \\
\text { stems branched. Flowers with } \\
\text { a brown corolla grow from } \\
\text { the leaf axils. }\end{array}$ & Purgative. & $\begin{array}{l}\text { Strzelecka and } \\
\text { Kowalski, 2000; } \\
\text { Podbielkowski and } \\
\text { Sudnik-Wójcikowska, } \\
\text { 2003. }\end{array}$ \\
\hline & $\begin{array}{l}\text { Plantago ovata } \\
\text { Forsk. }\end{array}$ & $\begin{array}{l}\text { South Europe, } \\
\text { south-west } \\
\text { Asia, South } \\
\text { America, North } \\
\text { America. }\end{array}$ & $\begin{array}{l}\text { Plant height } 20-40 \mathrm{~cm} \text {. } \\
\text { Linear, woolly haired leaves } \\
\text { form one or several ground } \\
\text { rosettes. The inflorescence is } \\
\text { a spike. }\end{array}$ & Mild purgative. & $\begin{array}{l}\text { Senderski, 2007; } \\
\text { Podbielkowski and } \\
\text { Sudnik-Wójcikowska, } \\
2003 \text {. }\end{array}$ \\
\hline & $\begin{array}{l}\text { Plantago } \\
\text { asiatica } \mathrm{L} .\end{array}$ & $\begin{array}{l}\text { Japan, Korea, } \\
\text { China, } \\
\text { Indochina, } \\
\text { Malaysia, } \\
\text { Taiwan, east } \\
\text { Siberia. }\end{array}$ & $\begin{array}{l}\text { Plant height } 30-50 \mathrm{~cm} \text {. } \\
\text { Entire leaves with a parallel } \\
\text { venation forming a ground } \\
\text { rosette. Small flowers borne } \\
\text { in a spike-like inflorescence. }\end{array}$ & $\begin{array}{l}\text { The herb is a detoxicating, } \\
\text { purgative, antipyretic } \\
\text { agent; it improves } \\
\text { eyesight; compress for } \\
\text { wounds. } \\
\text { Seeds - used in stomach } \\
\text { ulcer disease and } \\
\text { rhinoconjunctivitis; } \\
\text { compress for snakebites. }\end{array}$ & $\begin{array}{l}\text { Andrzejewska - Golec } \\
\text { and Makowczyńska, } \\
2005 .\end{array}$ \\
\hline & $\begin{array}{l}\text { Plantago depressa } \\
\text { Willd. }\end{array}$ & $\begin{array}{l}\text { Asia - from the } \\
\text { Ural Mountains } \\
\text { to China and } \\
\text { Japan. }\end{array}$ & $\begin{array}{l}\text { Plant height }>10 \mathrm{~cm} \text {. } \\
\text { Elliptical leaves, elliptical } \\
\text { - lanceolate to oval, erect; } \\
\text { they grow from a short stem. } \\
\text { Small, white flowers. }\end{array}$ & Purgative. & $\begin{array}{l}\text { Kletter snd } \\
\text { Kriechbaum, 2001; } \\
\text { www.eFloras.org }\end{array}$ \\
\hline
\end{tabular}




\section{Leaf anatomical characters}

The leaves of $P$. lanceolata show the isolateral structure. Diacytic stomata are distributed in the upper and lower epidermis. The mesophyll consists of 1-3 layers of palisade parenchyma, located on both sides of the epidermis, and a multi-layered spongy parenchyma situated in the central part of the lamella (Kohlmü n z e r, 1998; G o s t i n, 2009). In other plantain species, e.g. $P$. lessingii, the spongy parenchyma is poorly developed (Y u k u n , 1994). The largest spongy parenchyma cells in the leaves of $P$. lanceolata are found in the inner layers of the mesophyll, and their diameter decreases in the direction of the epidermis (Gostin, 2009). Vascular bundles and mucilage-accumulating cells are distributed in the mesophyll (Maurizio and Graf1, 1969).

Contrary to the previously mentioned species, the leaves of $P$. major have a structure typical for leaves of dicotyledons. They are characterized by 3 layers of palisade parenchyma on the side of the upper epidermis and several layers of spongy parenchyma on the side of the lower epidermis (O n o d a et al. 2008).

Glandular and non-glandular hairs occur on the leaf surface in representatives of the genus Plantago. The glandular trichomes can be club-shaped and they have a unicellular head or the head is divided vertically into two cells. The non-glandular trichomes located on the leaves of Plantago have different shapes and structures. They can be very short, 1-3-celled, slightly longer, consisting of 2-9 cells, or multicellular, composed of 14-40 cells. These hairs are characterized by a smooth or papillose cuticle (Andrzejewska- Golec and Ś więt tosław ski, 1993, 1998; A ndrzejewska-Golec, 2000, 2003).

\section{ALLERGENIC PROPERTIES OF Plantago POLLEN}

Likewise in many anemophilous plants, all Plantago species produce large amounts of pollen. It has been calculated that one stamen of $P$. lanceolata releases $7700-20000$ pollen grains, in $P$. media it is 6000 - 14000 pollen grains, while in P. major 5870 grains. One inflorescence of these species produces, respectively, 2 million, 3.3 million, and 6.3 million pollen grains (Kug ler, 1970; Św idziń ska, 1998; Pi otrowska, 2008). The research also shows that one flower of Plantago produces on average $1 \mathrm{mg}$ of pollen (M a rizi o and Graf 1, 1969).

Pollen grains of Plantago are spherical and multiporate with small verrucae on the exine surface (B e u g , 2004) (Figs. 1B-D). Their diameter is in the range of 16-35 $\mu \mathrm{m}$ (Wats on and Constable, 1991), while according to $\mathrm{B}$ e u g (2004) this value is the following for the respective species: Plantagolan- ceolata 22.3-27.8 $\mu \mathrm{m}$, Plantago major 19.5-27.0 $\mu \mathrm{m}$, Plantago media 27.0-32.0 $\mu \mathrm{m}$. The pore diameter in pollen grains of the above-mentioned species ranges from 2.0 to $6.0 \mu \mathrm{m}$. Pollen grains of $P$. major have a small number of pores (5-8), whereas this number is much higher for $P$. media (7-11) and $P$. lanceolata (9-15) (B e u g , 2004).

Species of the genus Plantago are included in the list of plants producing allergenic pollen (B a ld o et al. 1982; D' A m at o et al. 1991). Symptoms of allergy induced by the effects of $P$. lanceolata pollen have been recorded in North America, Europe, and Australia. Since the flowering period of all representatives of this family lasts several months and plants produce significant amounts of pollen, the risk of pollen allergy in sensitive people can continue for many weeks (W a t s o n and C on stable, 1991).

First pollen grains of Plantago are recorded in the air in particular regions of Poland at different times. They have been recorded earliest, already in the third decade of April, in Poznań and Łódź (M a j k o w s k a - Woj ci e chow ska et al. 2006; Stach, 2006), and latest (the second decade of May) in Szczecin and Lublin (P u c, 2006; Wery s zk o-Chmielew ska and Pi o trow s k a, 2006). Maximum concentrations of Plantago pollen grains in aeroplankton of different regions of Poland during the period 2001-2005 ranged 3-33 pollen grains per $1 \mathrm{~m}^{3}$ of air; these values were the highest in Sosnowiec, Rzeszów and Lublin, and the lowest in Poznań, Wrocław, and Łódź. Days with the maximum concentration were most frequently noted in different decades of July, less frequently in June or August (W e r y s z k o- C h m i e le w s k a, 2006).

$P$. lanceolata has the greatest allergenic importance. The most often described allergen is designated Pla $l 1$ and it has a weight of $16-20 \mathrm{kDa}$. It shows cross reactions with the olive allergen Ole e 1 ( $\mathrm{C}$ a 1 a b o z o et al. 2001).

\section{MEDICINAL USES}

Numerous species of the genus Plantago owe their properties to the presence of many biologically active substances, inter alia, glycosides, flavonoids, polysaccharides, and vitamins.

\section{Plantago lanceolata}

The leaf of ribwort plantain (Plantaginis lanceolatae folium) is raw material recognised in Polish Pharmacopoeia VI and European Pharmacopoeia 5. Raw material products are recommended for internal use in airway infections as well as mucosal inflammatory changes of the oral cavity and throat; externally, it is used in dermatitis. Biologically active substances found in ribwort plantain include, among others, iridoid glycosides, flavonoids, polysaccharides in the form 
of water soluble mucilages, and tannins (K o h $1 \mathrm{~m}$ ü n z e r, 1998).

The level of iridoid glycosides, which include aucubin and catalpol, in a natural population of $P$. lanceolata can reach even $9 \%$ of dry weight. Aucubin is a precursor in catalpol biosynthesis (B o w e r s , 1991). Other studies show that the level of aucubin and catalpol in the leaves of seven Plantago species was up to, respectively, $0.27 \%$ and $1.81 \%$ of leaf dry weight (J u ri š i ć et al. 2004).

Aucubin exhibits numerous pharmacological activities: antibacterial, anti-inflammatory, and it also facilitates healing of skin wounds. It can be useful in local treatment of oral wounds ( $\mathrm{S} \mathrm{him} \mathrm{et} \mathrm{al.} \mathrm{2007).}$ Aucubin is a specific inhibitor of NF-kB in mast cells, which may have a beneficial effect in the treatment of chronic allergic conditions ( $\mathrm{J}$ e o n g et al. 2002). This glycoside has been shown to have an antiproliferative effect on cancer cells (small-cell lung carcinoma), inducing their apoptosis ( $\mathrm{H} \mathrm{u} \mathrm{n} \mathrm{g} \mathrm{et} \mathrm{al.} \mathrm{2008).}$

Ground leaves or juice from fresh leaves of $P$. lanceolata are used to control external animal skin parasites. Both ethanol and aqueous extracts from leaves of this plant species have shown antihelminthic activity in mice (K o z a n et al. 2006).

Ribwort plantain is also used in the treatment of burns, insect bites, and stomach ulcers ( $\mathrm{S} \mathrm{tr} \mathrm{ze}$ le $\mathrm{c} \mathrm{k}$ a and K ow a 1 s k i , 2000; S a rw a , 2001). Leaf extracts have expectorant and antitussive effects as well as they exhibit immunotropic, adaptogenic, and diuretic activity (Andrzejewska-Golec, 1994). They are also used for eye irrigation in rhinoconjunctivitis ( $\mathrm{S}$ a muels e n, 2000; S a rw a, 2001).

\section{Plantago major}

Medicinal raw material is the leaf of common plantain (Plantaginis maioris folium) which contains iridoid glycosides, flavonoids, mucilaginous compounds, phenolic acids, tannins, triterpene compounds, vitamins $\mathrm{C}$ and $\mathrm{K}$ as well as mineral compounds (Kohlmünzer, 1998; Strzelecka and Kowalski, 2000).

Leaf extracts exhibit protective and anti-inflammatory effects in digestive tract diseases, bronchitis, and pharyngitis (Strzelecka and Kowalski, 2000).

Plantago major is a popular plant that has been used by Chinese medicine for many years to treat viral diseases, from common colds to viral hepatitis. Phenolic compounds (caffeic acid) isolated from the leaf extract of this plantain show strong antiviral activity, in particular against HIV-1 as well as HIV-2 and ADV-3 at multiplication stages ( $\mathrm{C} \mathrm{h}$ i a $\mathrm{g}$ et al. 2002).

$P$. major has properties stimulating the immune system. At specific doses, it causes proliferation of lymphocyte cultures. Seeds of this taxon show antidiarrhoeal activity (L a n s et al. 2007). One of flavo- noids found in plantain is baicalein which causes the death of cancer cells and inhibits the growth of human hepatoma cell lines (M ot o o and S a w a b u, 1994) as well as exhibits strong antiproliferative effects on rat liver cancer cultures (In o u e and Jackson, 1999). Numerous studies have shown that extracts of $P$. major have cytotoxic effects on cultures of different human cancer cell lines and human leukaemic cells (Matsukawa et al. 1993; Le Bail et al. 1998; Gálvez et al. 2005). S a muelsen (2000) reports about the antitumor use of $P$. major by folk medicine in the Canary Islands, Venezuela, Chile and Panama.

In the case of three other species: Plantago psyllium, $P$. arenaria, and P. ovata, medicinal raw material is the seed called Plantaginis semen. The seed coat contains mucilage and hemicellulose which cause a strong swelling of seeds. Mucilaginous compounds found in medicinal raw material contain xylose, rhamnose, arabinose, galactose, and uronic acids as well as sugars (planteose, glucose, and fructose), oil, phytosterols, aucubin, monoterpene, and triterpene alkaloids. Seeds of the aforementioned species are used as a protective and coating drug and also as a purgative. $P$. arenaria and $P$. ovata seeds have also been found to reduce the level of cholesterol ( $\mathrm{S} \mathrm{trze} \mathrm{le} \mathrm{k} \mathrm{k}$ and Kowalski, 2000; Senderski, 2007). Seed husks of $P$. ovata and $P$. psyllium are currently used in the pharmaceutical industry ( $\mathrm{Ch}$ a $\mathrm{n}$ and Wypyszyk, 1988; D h a r et al. 2000; 2005).

Rozaeipoor et al. (2000) showed that an extract of $P$. ovata seeds significantly affected the immune system of rabbits. It caused a reduction in anti-HD antibodies as well as an increase in the number of white blood cells and spleen leukocytes. The aqueous extract of $P$. ovata seeds reduced hyperglycaemia in type 1 and 2 diabetes in rats. These properties show that this extract can be used in diabetes treatment (K o r d o šo vá and M a chová, 2006).

Treatment with $P$. ovata seed coat preparations increases and stabilises the level of HDL - cholesterol, thereby reducing the risk factors of cardiovascular system diseases (S o 1 à et al. 2007).

\section{APPLICATION IN COSMETICS}

Plantago lanceolata and P. major are included in the list of cosmetic plants. Aqueous infusions and stabilised fresh juice from leaves of these both plantain species are used in cosmetics. Antiseptic, antibacterial, and astringent effects of their leaves are utilised ( $\mathrm{P} \mathrm{o} \mathrm{d}$ bielkowski and Sudnik-Wójcikowska, 2003; Czerpak and Jabłońska-Trypuć, 2008). The extract from the leaves of $P$. lanceolata is used to produce different cosmetics, among others, creams, lotions as well as face masks for oily and acne 
skin (P o d bi e lk ow ski, 1992; J ę d r ze jk o et al. 2007).

Other authors ( $\mathrm{H} \mathrm{l} \mathrm{a} v \mathrm{v}$ et al. 1984) recommend the use of crushed fresh leaves of $P$. lanceolata in face masks. These researchers also mention the species of $P$. psyllium whose seeds contain up to $10 \%$ of mucilage and are used to prepare a macerate in cold water and subsequently to produce nourishing creams and lotions. The literature confirms that seed husks of $P$. ovata and $P$. psyllium have found application in the cosmetics industry (D h a r et al. 2005).

\section{Plantago AS AN EDIBLE PLANT}

Plantago major was used as a vegetable in China and by North American Indians, for example, from the Cherokee and Mohican tribes ( $\mathrm{u} \mathrm{c} \mathrm{z} \mathrm{a} \mathrm{j} \mathrm{,} \mathrm{2004).}$

Leaves of different Plantago species are eaten raw or cooked, and their taste is compared to that of chard. Only young leaves are consumed in the form of salads, since older ones are fibrous and bitter ( $\mathrm{Cl}$ a r k, 1977; Ł u c z a j, 2004). In Italy Plantago lanceolata leaves are used as an addition to salads or are eaten like lettuce (S a m u els e n, 2000; He i m ler et al. 2007).

Plantain leaves are also used as an addition to soups and as a cooked vegetable. In the past, people used to eat them especially during the spring period when vegetables were in short supply ( $\mathrm{S}$ a $\mathrm{m} \mathrm{u}$ e $\mathrm{ls}$ e $\mathrm{n}$, 2000). The leaves of P. maritima are tasty and they are added to chicken soup in France, whereas the leaves of $P$. coronopus are used in salads in Italy and France. Leaves of different plantain species can be fried in pastry ( $\mathrm{E} \mathrm{u} \mathrm{c} \mathrm{z} \mathrm{a} \mathrm{j} \mathrm{,} \mathrm{2004),} \mathrm{while} P$. lanceolata leaves can be used to prepare an infusion, tea, tincture, wine, juice, and macerate (C l a r k, 1977).

Plantago seeds can be cooked as groats or, after grinding, they are added to cakes and bread ( $\mathrm{E} \mathrm{u} \mathrm{c} \mathrm{z} \mathrm{a} \mathrm{j}$ 2004; D h a r et al. 2005). They are also included in breakfast cereals, ice cream, or instant beverages (D h a r et al. 2000, 2005). Aqueous extracts of $P$. ovata seed husks are recommended in diets for diabetics, since they have been found to reduce hyperglycaemia in type 1 and 2 diabetes ( $\mathrm{H} \mathrm{ann}$ a n et al. 2006).

\section{PLANTAIN LEAVES AS ANIMAL FEED}

Herbs are used more and more widely as animal feed ingredients. They are used individually or in the form of herbal mixtures added to nutritious feeds for all animal species (Fritz and Gre la, 1995).

The positive effects of herbs on animal organism consist in improving the taste and smell of animal fodder, regulating digestive functions, increasing resistance to infections, and contributing to the characteri- stics of meat and fat desired by the consumer ( $\mathrm{G} \mathrm{r} \mathrm{e} \mathrm{l} \mathrm{a,}$ 1995).

Plantago lanceolata is a plant that is officially allowed in animal nutrition ( $\mathrm{Gre} \mathrm{la}$, 1997). It was demonstrated that the addition of herbal mixture containing $P$. lanceolata in the feeding of porkers improved meat taste and increased the amount of unsaturated acids, which is a desired feature in human nutrition (Gre la and B aranowska, 1999). P. lanceolata stems are recommended as a food integrator for rabbits and other animals (C o r n a r a et al. 2009). On the other hand, seeds dried, roasted, or milled for flour are used as food for cage birds. Seeds of this plantain are a delicacy for canaries (C la r k, 1977; F i j a ł k o w s k i and Chojnacka-Fijałkowska, 2009).

\section{Acknowledgements}

Research supported by the Ministry of Science and Higher Education of Poland as the part of statutory activities of Department of Botany, University of Life Sciences in Lublin.

\section{REFERENCES}

Andrzejewska-Golec E., 1994. Ontogeny of trichomes in taxa of the genus Plantago subg. Psyllium (Plantaginaceae). Acta Soc. Bot. Pol. 63: 199-204.

Andrzejewska-Golec E., 2000. The hairs in species of Plantago L. section Palaeopsyllium Pilg. (Plantaginaceae). Feddes Repert. 111 (1-2): 9-14.

Andrzejewska-Golec E., 2003. The hairs of Plantago reniformis Beck, section Eremopsyllium Pilg. (Plantaginaceae). Feddes Repert. 114 (3-4): 204-207.

Andrzejewska-Golec E., Makowczyńska J., 2005. Babka azjatycka (Plantago asiatica L.) - roślina lecznicza Dalekiego Wschodu / Asian plantain - a plant from the Far East. Post. Fitoter. 1-2: 29-34. (in Polish)

Andrzejewska-Golec E., Świętosławski J., 1993. Hair anatomy in Plantago subg. Psyllium (Plantaginaceae). Pl. Syst. Evol. 184: 113-123.

Andrzejewska-Golec E., Świętosławski J., 1998. Microhairs of Plantago maritima L. under electron scaning microscopy. Feddes Repert. 109 (3-4): 225-229.

Anioł-Kwiatkowska J., Kwiatkowski S., Berdowski W., 1993. Rośliny lecznicze: atlas. Wyd. “Arkady”, Warszawa (in Polish).

Baldo B.A., Chensee Q.J., Howden M.E.H., Sh arps P. J., 1982. Allergens from Plantain (Plantago lanceolata). Studies with pollens and plant extracts. Int. Archs. Allergy Appl. Immunol. 68: 295-304.

B e ug H. J., 2004. Leitfaden der Pollenbestimmung für Mitteleuropa und angrenzende Gebiete, Verlag Dr Friedrich Pfeil, München. (in German)

B owers M.D., 1991. Iridoid glycosides. In: G.A. Resenthal, M.R. Berenbaum (eds.). Herbivores: Their interaction 
with secondary plant metabolites. Academic Press, San Diego.

Calabozo B., Duffort O., Carpizo J.A., Barber D., Polo F., 2001. Monoclonal antibodies against the major allergen of Plantago lanceolata pollen, Pla $l 1$ : affinity chromatography purification of the allergen and development of an ELISA method for Pla $l$ 1 measurement. Allergy, 56(5): 429-435.

Chan J.K.C., Wy pyszyk V., 1988. A forgotten natural dietary fiber: psyllium mucilloid. Cereal Food World 33: 919-922.

Chiang L.C., Chiang W., Chang M.Y., Ng L.T., Li in C.C., 2002. Antyviral activity of Plantago major extracts and related compounds in vitro. Antiviral Res. 55: 53-62.

Clark Ch.B., 1977. Edible and useful plants of California. University of California Press, Berkley.

Cornara L., Rocca A.La., Marsili S., Mariotti M.G., 2009. Traditional uses of plants in the Estern Riviera (Liguria, Italy). J. Ethnopharmacol. 125: 16-30.

Czerpak R., Jabłońska-Trypuć A., 2008. Roślinne surowce kosmetyczne. MedPharm Polska, Wrocław. (in Polish)

D'A mato G., Spieksma F.Th., Bonini S., 1991. Allergenic Pollen and Pollinosis in Europe. Blackwell Scientific Publications, Oxford.

Dhar M.K., Kaul S., Jamwal S., 2000. Plantago ovata Forsk. In: Gupta S.K. (ed.) Plant Breeding: Theory and Techniques. Jodhpur, India Agrobis.

Dhar M.K., Kaul S., Sareen S., Koul A.K., 2005. Plantago ovata: genetic diversity, cultivation, utilization and chemistry. Plant Gen. Res. 3(2): 252-263.

Fijałkowski D., Chojnacka-Fijałkowska E., 2009. Rośliny lecznicze na Lubelszczyźnie. Wyd. Olech, Lublin (in Polish).

Fritz Z., Grela E.R., 1995. [In:] Dodatki paszowe dla świń. M. Kotarbińska, E.R. Grela (eds). Polska Akademia Nauk Instytut Fizjologii i Żywienia Zwierząt im. Jana Kochanowskiego, Warszawa (in Polish).

Gálvez M., Martin-Cordero C., Houghton P.J., Ay u so M. J., 2005. Antioxidant activity of Plantago bellari All. Phytother. Res. 19: 1074-1076.

Gostin I.N., 2009. Structural modification induced by air pollutants in Plantago lanceolata leaves. Analele Universitătii din Oradea, Fascicula Biologie, XVI (1): 61-65.

Grela E.R., 1995. Przydatność ziół w żywieniu świń. / The usefulness of herbs in feeding pigs. Trzoda Chlewna 33(4): 18-19 (in Polish).

Grela E.R., 1997. Zioła w żywieniu zwierząt gospodarskich. / Herbs in feeding farm animals. Lek w Polsce. Weterynaria 3(18): 19-33 (in Polish).

Grela E.R., Baranowska M., 1999. Efektywność wybranych ziół w tuczu świń. / Effectiveness of selected herbs in pig fattening. Trzoda Chlewna, 37(12): 73-77 (in Polish).
Hannan J.M.A., Ali L., Khaleque J., Akhter M., Flatt P.R., Abdel-Wahab Y.H.A., 2006. Aqueous extracts of husks of Plantago ovata reduce hyperglycaemia in type 1 and type 2 diabetes by inhibition of intestinal glucose absorbtion. Brit. J. Nutr. 96: 131-137.

Heimler D., Isolani L., Vignolini P., Tombelli S., Romani A., 2007. Polyphenol content and antioxidative activity in some species of freshly consumed salads. J. Agric. Food Chem. 55: 1724-1729.

Hlava B., Star F., Pospíšil F., 1984. Rośliny kosmetyczne. Państwowe Wydawnictwo Rolnicze i Leśne, Warszawa (in Polish).

Hung J.Y., Yang C.I., Tsai Y.M., Huang H.W., Huang M.S., 2008. Antiproliferative activity of aucubin in through cell cycle arrest and apoptosis in nonsmall cell lung cancer A549 cells. Clin. Exp. Pharmacol. Physiol. 35: 995-1001.

In oue T., Jacks on E.K., 1999. Strong antiproliferative effects of baicalein in cultured rat hepatic stellate cells. Eur. J. Pharmacol. 378(1): 129-135.

Jeong H.J., Koo H.N., Na H.J., Kim M.S., Hong S.H., Eom J.W., Kim K.S., Shin T.Y., K im H.M., 2002. Inhibition of TNF- and IL-6 production by aucubin through blocade of NF- B activation in RBL-2H3 mast cells. Cytokine 18: 252-259.

Jędrzejko K., Kowalczyk B., Bacler B., 2007. Rośliny kosmetyczne. Wydawnictwo Śląskiego Uniwersytetu Medycznego, Katowice.

Jurišić R., Debeljak Ž., Vladimir-Knežević S., 2004. Determination of aucubin and catalpol in Plantago species by micellar electrokinetic chromatography. Z. Naturforsch. 59c: 27-31.

Kletter C., Kriechbaum M. (eds), 2001. Tibetan Medicinal Plants. Taylor \& Francis Inc., London.

Kohlmünzer S., 1998. Farmakognozja. Podręcznik dla studentów farmacji. Państwowe Zakłady Wydawnictw Lekarskich, Warszawa (in Polish).

Kordošová A., Machová E., 2006. Antioxidant activity of medicinal plants polysaccharides. Fitoterapia, 77: 367-373.

Kozan E., Küpeli E., Yesilada E.,2006. Evaluation of some plants used in Turkish folk medicine against parasitic infections for their in vivo anthelmintic activity. J. Ethnopharm. 108: 211-216.

Kugler H.G., 1970. Blütenökologie. Gustav Fischer Verlag, Stuttgart (in German).

Lans Ch., Turner N., Khan T., Brauer G., Boepple W., 2007. Ethnoveterinary medicines used for ruminants in British Columbia, Canada. J. Ethnobiol. Ethnomed. 3: 11.

Le Bail J.C., Varnat F., Nicolas J.C., Habrio u x G., 1998. Estrogenic and antiproliferative activities on MCF-7 human breast cancer cells by flavonoids. Cancer Lett. 130(1-2): 209-216.

Li piński M., 2010. Pożytki pszczele. Zapylanie i miododajność roślin. Powszechne Wydawnictwo Rolnicze 
i Leśne, Warszawa; Wyd. Sądecki Bartnik, Stróże (in Polish).

Łuczaj Ł., 2004. Dzikie rośliny jadalne Polski. Przewodnik survivalowy. Chemigrafia, Krosno (in Polish).

Majkowska-Wojciechowska B., Balwierz Z., Wojciechowski Z., Jarzębska M., Kowalski M.L., 2006. Analiza stężenia ziarn pyłku w aeroplanktonie Łodzi w sezonach 2003-2005. [In:] Pyłek roślin w aeroplanktonie różnych regionów Polski. E. Weryszko-Chmielewska (ed.). Katedra i Zakład Farmakognozji z Pracownią Roślin Leczniczych Wydziału Farmaceutycznego Akademii Medycznej im. Prof. Feliksa Skubiszewskiego, Lublin (in Polish).

Matsukawa Y., Marui N., Sakai T., Satomi Y., Yoshida M., Matsumoto K., Nishino H., A oike A., 1993. Genistein arrest cell cycle progression at G2-M. Cancer Res. 53(6): 1328-1331.

Maurizio A., Grafl I., 1969. Das Trachtpflanzenbuch. Ehrenwirth Verlag, München (in German).

Mirek Z., Piękoś-Mirkowa H., Zając A., Zając M. (eds), 2002. Flowering plants and pteridophytes of Poland a checklist. W. Szafer Institute of Botany, Polish Academy of Sciences, Kraków (in Polish).

Moto o Y., S awabu N., 1994. Antitumor effects of saikosaponins, baicalin and baicalein on human hepatomacell lines. Cancer Lett. 86(1): 91-95.

$\mathrm{Nishibe} \mathrm{S.,} \mathrm{2002.} \mathrm{The} \mathrm{plant} \mathrm{origins} \mathrm{of} \mathrm{herbal} \mathrm{medicines}$ and their quality evaluation. Yakugaku Zasshi 122(6): 363-379.

Nowiński M., 1983. Dzieje upraw i roślin leczniczych. Państwowe Wydawnictwo Rolnicze i Leśne, Warszawa (in Polish).

Onoda Y., Schieving F., Anten N.P.R., 2008. Effects of light nutrient availability in leaf mechanical properties of Plantago major: a conceptual approach. Ann. Bot. 101: 727-736

Pi otrowska K., 2008. Pollen production in selected species of anemophilous plants. Acta Agrobot. 61(1): 41-52.

Podbielkowski Z., 1992. Rośliny użytkowe. Wydawnictwa Szkolne i Pedagogiczne, Warszawa (in Polish).

Podbielkowski Z., Sudnik-Wójcikowska B., 2003. Słownik roślin użytkowych. Państwowe Wydawnictwo Rolnicze i Leśne, Warszawa (in Polish).

Podhajská Z., Rivola M., 1992. Wielka Encyklopedia Roślin. Oficyna Wydawnicza „Delta W-Z”, Warszawa (in Polish).

P u c M., 2006. Pyłek wybranych taksonów roślin w powietrzu Szczecina 2001-2005. [In:] Pyłek roślin w aeroplanktonie różnych regionów Polski. E. Weryszko-Chmielewska (ed.). Katedra i Zakład Farmakognozji z Pracownią Roślin Leczniczych Wydziału Farmaceutycznego Akademii Medycznej im. Prof. Feliksa Skubiszewskiego, Lublin (in Polish).

Reardon W., Fitzpatrick D.A., Fares M.A., Nugent J.M., 2009. Evolution of flower shape in Plantago lanceolata. Plant. Mol. Biol. 71:241-250.
Rezaeipoor R., Saeidnia S., Kamalinejad M., 2000. The effect of Plantago ovata on humoral immune responses in experimental animals. J. Ethnopharm. 72(1-2): 283-286.

Samuelsen A.B., 2000. The traditional uses, chemical constituents and biological activities of Plantago major L. A review. J. Ethnopharm. 71: 1-21.

S a rwa A ., 2001. Wielki leksykon roślin leczniczych. Wyd. Książka i Wiedza, Warszawa (in Polish).

Senderski M.E., 2007. Prawie wszystko o ziołach. Wyd. M.E. Senderski, Podkowa Leśna (in Polish).

Shim K.M., Choi S.H., Leong M.J., Kang S.S., 2007. Effects of aucubin on the healing wounds. In Vivo 21: 1037-1041.

Solà R., Godàs G., Ribalta J., Vallvé J.C., Girona J., Anguera A., Ostos M.A., Recalde D., Salazar J., Caslake M., MartínLuján F., Salas-Salvadó J., Masana L., 2007. Effects of soluble fiber (Plantago ovata husk) on plasma lipids, lipoproteins and apolipoproteins in men with ischemic heart disease. Am. J. Clin. Nutr. 85: 1157-1163.

Stach A., 2006. Pyłek wybranych taksonów roślin w powietrzu Poznania, 2001-2005. [In:] Pyłek roślin w aeroplanktonie różnych regionów Polski. E. Weryszko-Chmielewska (ed.). Katedra i Zakład Farmakognozji z Pracownią Roślin Leczniczych Wydziału Farmaceutycznego Akademii Medycznej im. Prof. Feliksa Skubiszewskiego, Lublin (in Polish).

Strzelecka H., Kowalski J. (eds), 2000. Encyklopedia zielarstwa i ziołolecznictwa. Wydawnictwo Naukowe PWN, Warszawa (in Polish).

Szweykowska A., Szweykowski J. (eds), 2003. Słownik botaniczny. Wiedza Powszechna, Warszawa (in Polish).

Św id z ińs k a M. (ed), 1998. Wielka Encyklopedia Przyrody. Rośliny kwiatowe 2. Muza SA, Warszawa (in Polish).

Truchan M., 2005. Międzypopulacyjne zróżnicowanie owoców i nasion Plantago lanceolata L. / Interpopulation variation in fruits and seeds of Plantago lanceolata. Słupskie Prace Biologiczne 2: 135-146 (in Polish).

Weberling F., 1992. Morphology of flowers and inflorescences. Cambridge University Press.

Watson H.K., Constable D.W., 1991. Allergenic significance of Plantago pollen. In: D’Amato G., Spieksma F.Th., Bonini S. Allergenic Pollen and Pollinosis in Europe. Blackwell Scientific Publications, Oxford.

Weryszko-Chmielewska E., (ed.) 2006. Pyłek roślin w aeroplanktonie różnych regionów Polski. Katedra i Zakład Farmakognozji z Pracownią Roślin Leczniczych Wydziału Farmaceutycznego Akademii Medycznej im. Prof. Feliksa Skubiszewskiego, Lublin (in Polish).

Weryszko-Chmielewska E., Piotrowska K., 2006. Pyłek wybranych taksonów roślin w powietrzu Lublina, 2001-2005. [In:] Pyłek roślin w aeroplanktonie różnych regionów Polski. E. Weryszko-Chmielewska 
(ed). Katedra i Zakład Farmakognozji z Pracownią Roślin Leczniczych Wydziału Farmaceutycznego Akademii Medycznej im. Prof. Feliksa Skubiszewskiego, Lublin (in Polish).

Yukun R., 1994. A study on the anatomy and environment of leaves of Plantago lessingii Pisch et wey. Journal of Ningxia Agricultural College. CNKI: SUN: LXLX.O.1994-04-007 (in Chinese).

www.eFloras.org

\section{Właściwości użytkowe roślin z rodzaju Plantago}

\section{Streszczenie}

Wielowiekowe doświadczenia medycyny ludowej, tradycje żywieniowe oraz wyniki licznych badań naukowych wskazują, że rośliny z rodzaju Plantago mogą być wykorzystywane w celach leczniczych, kosmetycznych, dietetycznych oraz rytualnych.

W składzie fitochemicznym Plantago występuje bogactwo substancji biologicznie czynnych (m. in., glikozydy, flawonoidy, polisacharydy i witaminy) o korzystnym działaniu, przy jednoczesnej niewielkiej zawartości związków o właściwościach toksycznych. Badania naukowe potwierdziły, że rośliny te mają właściwości antyoksydacyjne, hamujące apoptozę, osłania- jące, przyspieszające procesy gojenia, spazmolityczne, przeciwrobacze, przeciwdrobnoustrojowe, hamujące rozwój niektórych nowotworów, a także obniżające poziom lipidów we krwi oraz hamujące procesy glikacji w tkankach. W fitoterapii stosuje się liście, pędy lub/i nasiona różnych gatunków babki.

Liście i nasiona Plantago znajdują także zastosowanie do wyrobu kremów, lotionów i maseczek. Różne części tych roślin (świeży surowiec, ekstrakty lub wyizolowane substancje) wykorzystywane są również w żywieniu ludzi i zwierząt. Liście babki można spożywać jak sałatę, smażyć w cieście, przyrządzać $\mathrm{z}$ nich herbatę, sok czy wino. Nasiona dodawane są do ciastek, chleba, płatków śniadaniowych, lodów, napojów lub gotowane są jak kasza. Zwierzęta karmione babką mogą żyć dłużej i są zdrowsze, zaś mięso z nich pochodzące jest smaczniejsze i zdrowsze dla ludzi. Nasiona Plantago są chętnie zjadane przez ptaki utrzymywane w klatach.

Natomiast pyłek babki ma właściwości alergizujące. Produkowany w dużych ilościach (do 20 tys. ziaren pyłku/1 pręcik $P$. lancolata) może wywoływać alergie u osób wrażliwych. $\mathrm{Z}$ uwagi na długi okres kwitnienia roślin z rodzaju Plantago, działanie czynnika alergizującego utrzymuje się przez wiele tygodni. W Polsce dni z maksymalną koncentracją ziaren pyłku babki w powietrzu najczęściej występują w lipcu. 
